\title{
On the Limits of Rentier State Theory: An epistemological Insight
}

\author{
Elmekdad Shehab ${ }^{1}$ \\ ${ }^{1} \mathrm{PhD}$ Student, Gulf Studies Depratment, Collage of Arts and Sciences, Qatar University, Doha, Qatar \\ Correspondence: Elmekdad Shehab, Gulf studies depratment, Collage of Arts and Sciences, Qatar University, P.O. \\ Box 2713, Doha, Qatar. E-mail: es1706069@qu.edu.qa
}

\author{
Received: April 3, $2021 \quad$ Accepted: July 14, $2021 \quad$ Online Published: July 31, 2021 \\ doi:10.5539/ass.v17n8p30 \\ URL: https://doi.org/10.5539/ass.v17n8p30
}

\begin{abstract}
For decades, The rentier state theory has provided the most popular explanations for the sociopolitical dynamics in the Arab Gulf states, however, due to the rapid transformations in the Gulf societies in recent years, the theory went under severe critiques especially after its failure to predict the emergence of a new Gulf social contract after the oil crisis of 2014. This essay has tried to shed the light on one of the missing dimensions of these critiques by arguing that this failure might have occurred because the rentier state theory adhered to an obsolete epistemological paradigm of modernity that was incapable of dealing with such a complex social phenomenon from the beginning. Also, seeking epistemic healing, the essay highlighted the most recent shift in the philosophy of science toward a complexity paradigm and referred to its potentials to exceed the limits of the rentier paradigm.
\end{abstract}

Keywords: Arab Gulf states, social contract, rentier state theory, complexity, modernization

\section{Introduction}

After more than a year of living under the new circumstances of the Covid-19 global pandemic, the observer can see the domino effect of this pandemic, which has disrupted local politics and the global economy and has struck mercilessly on every aspect of our species' life. This new reality has prompted some academics to call for a rethinking of how we run our politics and society, and some have even spoken of a "post-pandemic world" (Zakaria, 2020), as they realized that the ideas and beliefs that had prevailed prior to the pandemic would not be able to withstand the aftermath.

When it comes to the Gulf states and societies, however, there is only one theoretical framework that has sat on the throne and been described as the most influential paradigm on the field for more than five decades, and that is the Rentier State theory (Herb, 2002). Every act was taken by the Arab Gulf governments, every unique behavior of the Gulf societies and every significant outcome from its development process was by one way or another analyzed or defined by the rentier state theory!

Therefore, this article is aimed at shedding light on some drawbacks of the rentier theory, by focusing on its failure to predict the new socio-political dynamics that took place in the Gulf after the oil crisis in 2014. This will consume the first part of the paper, while the second part will be dedicated to explaining how this failure happened by tracing the epistemological basis of the rentier theory where I assume that this failure began. Then, I will conclude with a call raised by some scholars for a new paradigm that can meet our new complex social reality.

\subsection{Research Problem and Literature Review}

More than five decades have passed since the energy resources ignited the transformation of the economies and societies in the Persian Gulf states. The energy wealth fueled the development process, gave the region a new geopolitical weight, and shaped its internal and external relationships. Meanwhile, the citizens of the Gulf become more educated, healthier, and enjoying the opportunities that were impossible without this energy resource wealth and live understates with a comprehensive welfare system. These huge impacts of the energy in the societies caught the attention of the social scholars who tried to reveal the social and political aspects of the energy resources in the Gulf context, and their respectable efforts were culminated with what we call it today "rentier paradigm".

Overall, the Rentier paradigm consisted of two theories (Rutledge, 2017), namely, the rentier state theory and 
resource curse theory, both have prevailed over the explanation of social and political aspects in the Gulf context and both have developed and intertwined to cope with the undergoing development of the Gulf states and society after the initial impact of the oil boom in 1971. While Rentier state theory focuses on the political aspects and arguing that natural resources when forms the major source of income for the state, tends to determine a country's politics, and most probably lead to authoritarian rule (Desai, Olofsgard, \& Yousef, 2009) because rentier government avoid extraction of taxes from its people and buy their consent by the welfare leverages (Beblawi \& Luciani, 1987). The resource curse literature built on the assumption that dependence on one commodity revenues, like oil and gas tend to produce a slower economic growth (Sachs \& Warner, 1995) that could undermine the economic development itself because it is exposed to "Dutch disease" (Corden \& Neary, 1982) which defined as a rise in the real exchange rate, dismantling of the "traded sector" of the economy (particularly agriculture and manufacturing ones) and flourishing in the "nontraded sector" (namely; construction, retail, and services). also, it could lead to hinder democracy (Ross, 2007, 2012) and promote conflicts and civil wars. (Collier \& Hoeffel, 2004).

Rentier theory was established by political scholars in seeking to explain the political survival of the family ruling in the middle east especially after it's vanished everywhere else and as a response to the failure of the modernization theory which assumed that all societies would turn to democracy if they achieve economic growth and rising wealth. (Huntington, 1968). From this point, the focus of the rentier theory was the trying to find a correlation between the survival of family-based ruling in the Gulf and the abundance of the state revenue from the natural resources.

It was 1987 when Biblawi and Luciani published their seminal work The Rentier State which offered a new vision of the state-society relationship. Beblawi and Luciani argued that the oil wealth enabled the ruling families to enhance their autocratic role and defeating their rivals like tribal sheiks and merchants who had played a political role before the oil era, and their role has replaced by the share of wealth. In this way, the rent set up a new balance of power that favored ruling families (Beblawi \& Luciani, 1987). The result was to free the state's income from the domestic economy obligations by the external flow of oil and gas, which means it doesn't need anymore the skills or depend on the productivity of their population (Beblawi \& Luciani, 1987). Beblawi and Luciana mentioned that the rentier economy has particular features, the most significant one is the "allocative" character of the state against the normal "extractive" one, so they argue that the rentier state didn't need to develop a real economic policy as "expenditure policy" was enough (Luciani, 1987).

In the same line. Michael Ross in 2011 asking, "does oil hinders democracy?" and seeks correlations between natural resources and autocracy, he argued that rents - when it is controlled by the government, gives the ability to allocate the revenues without the need to build institutions that tax the society, which made the ruling elites "buy" the public support in exchange for welfare services. (Rose, 2001). By using time- series cross-national data from 113 states between 1971 and 1997, Ross studied the three major effects that oil makes, the modernization effect which means the activities of the state that encourage social change, and the rentier effect which means the role of rent in buying the consent of the citizens in exchange for some welfare privileges, and development effect which indicates to the economic growth in those countries. Ross found a statistical correlation for oil to inhibit democracy (rentier effect) and found no correlation for oil in inhabiting the modernization or development activities.

Ross then expanded his work on a separate book in 2012 and used case studies along with panel data to support his argument, he referred to the first oil shock 1970s as a began when Regimes took advantage of the wealth that accumulated in their pocket for blocking the democracy (Ross, 2012). in the same line, another influential paper by Desai, Olofsard, and Yousef in 2009 proposes new evidence for the rentier "authoritarian bargain" thesis and prove its validity across a panel of 80 autocracies. They found that the state has captured people's political rights in exchange for welfare privileges, which eventually led to blocking democracy (Desai, Olofsgard, \& Yousef, 2009)

In sum, the rentier paradigm has provided the most popular explanations for the sociopolitical dynamics in the Arab Gulf States, as it had emphasized that the secret of the stability of Gulf regimes and lacking the democracy in the region lie in their exchange the monopoly on power by distributing the revenues of the wealth to their citizens, or in other words replacing political legitimacy with welfare benefits and subsidies. Accordingly, the rentier theory literature predicted that any potential changes in this unwritten contract will inevitably lead to disturb the Gulf regimes Stability and raise the demand for democracy (e.g., Karl, 1997, 2007; Gause, 1994, 1997; Ross, 2012), because these subsidies and benefits are "neither retract nor restrict" (Krane, 2019).

However, this claim was proven to be wrong on the ground in 2014, as the oil price crisis hit all Gulf countries, 
and the price per barrel decreased from $\$ 114$ to $\$ 30$, which put the Gulf States in fiscal trouble for not being able to balance their budgets (Krane, 2019), in turn, forced Each of the six monarchies to cut their expenditures, raised prices on transportation fuel and electricity and water for the commercial sector and roll back some subsidies and welfare benefits especially in the energy sector (Figure $1 \& 2$ )

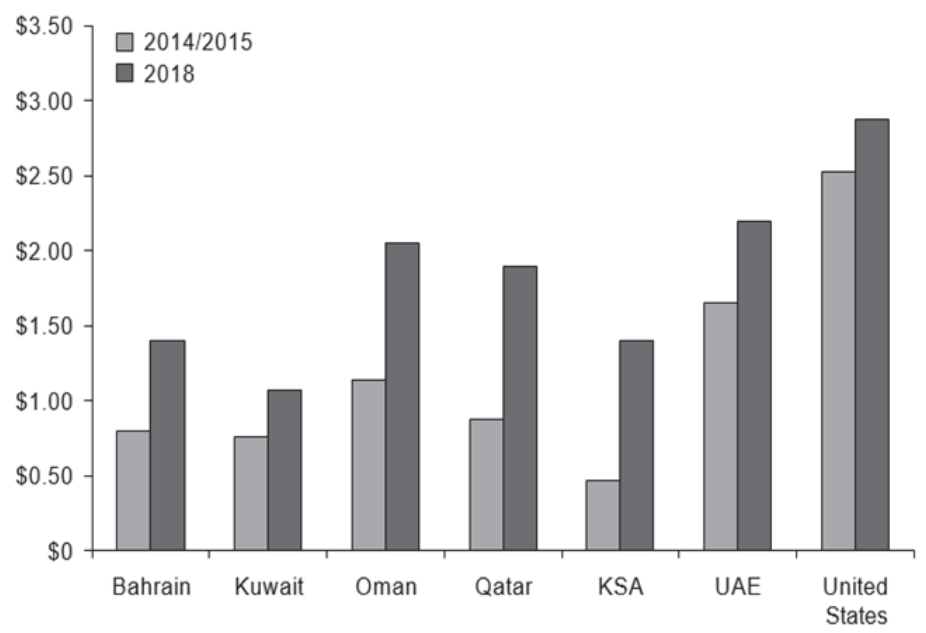

Figure 1. Change in regular gasoline price (\$US/ gallon) after subsidy cut (Krane, 2019)

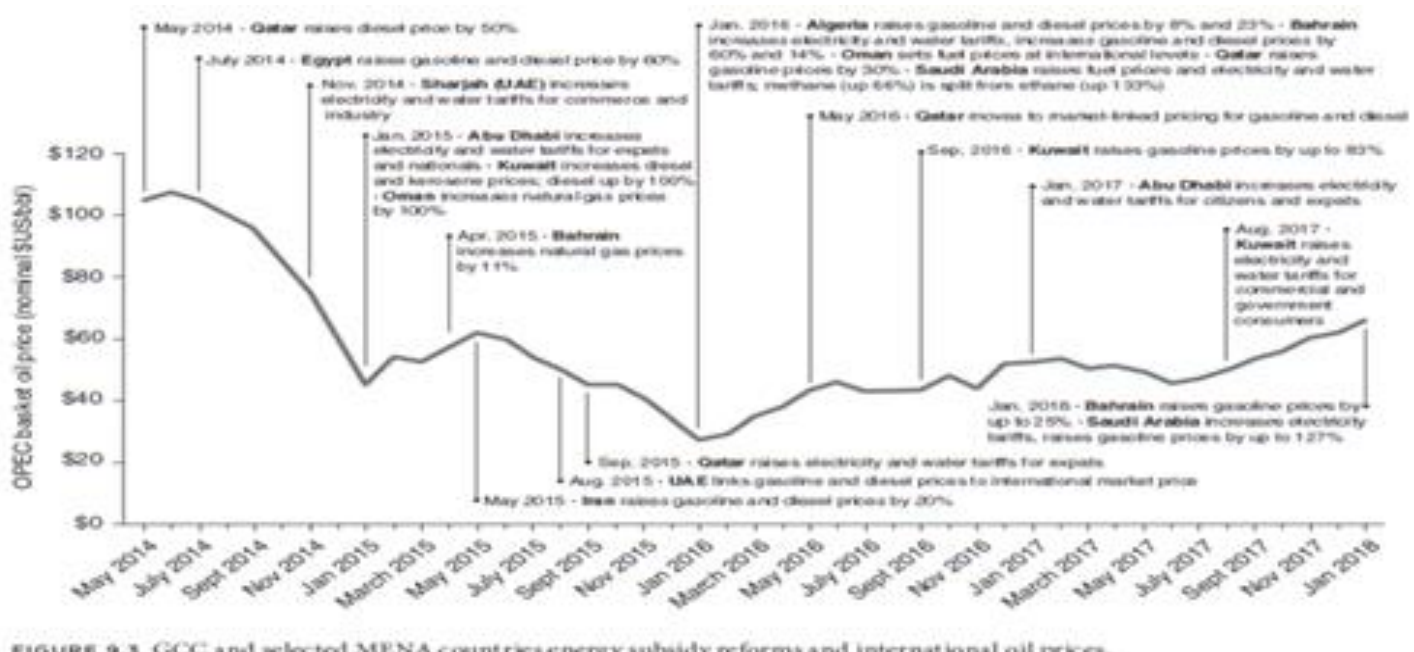

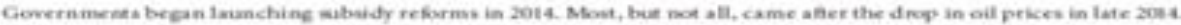

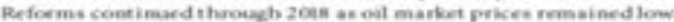

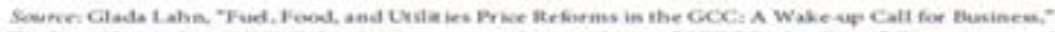

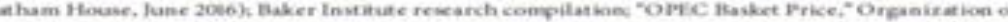

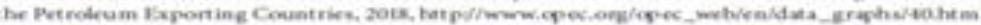

Figure 2. GCC and selected MENA Countries Energy subsidy reforms and international oil prices (Krane, 2019)

\subsection{Research Question}

According to rentier theory, this rollback of the welfare privileges was supposed to be possible "only if the state enjoys solid democratic legitimation" (Beblawi \& Luciani, 1987) Otherwise, "the future of their political systems could be called into question" (Gause, 1997; Krane, 2014) but since the evidence on the ground after 2014 shows that neither governments nor citizens had followed the script laid out by rentier state theory. So, the question that this essay asking is how this shortcoming happened? and what are the root causes behind it?

\section{Analysis}

\subsection{Krane's Argument}

One of the latest trials to fix the rentier state theory was done by Jim Krane in who tried in his book Energy 
Kingdoms: Oil and Political Survival in the Persian Gulf to answer this puzzle without attacking the core of the theory itself by introducing an explanation for its failure and proposing a modification that could keep it valid. Simply, the core of Krane's thesis is that four reasons came together in one moment that made it easy for the Gulf rulers to change their rentier social contract without putting their legitimacy into question. These reasons are:

1- The financial crisis itself justified the reduction of expenditures as a non-traditional response to the exceptional challenge.

2- Rising the domestic consumption of energy as a result of the decades of subsidizing energy for citizens and business owners, which escalating intensely, especially in the Kingdom of Saudi Arabia, where domestic consumption consumes a quarter of the Kingdom's oil production (Figure 3).

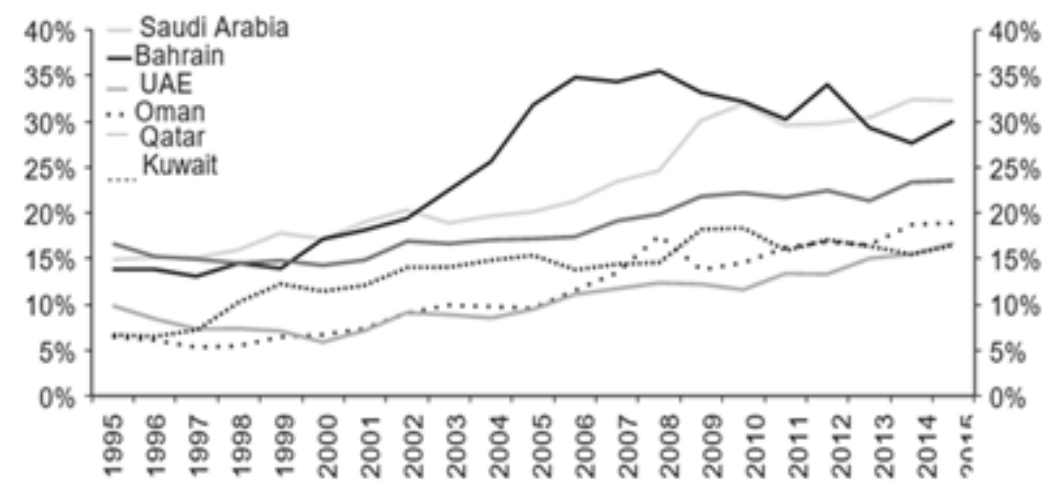

Figure 3: Demotic oil consumption as a percentage of domestic oil production, 1995 -2016 Includes natural gas liquids LNG. (Krane, 2019)

3- The security crisis that exploded in the region aftermath of the Arab Spring, and the subsequent rise of the ISIS threat, which made the issue of security and maintaining standards of living a top priority for citizens in the Gulf.

4- The rise of new leaders in the most effective Gulf States such as Saudi Arabia, the Emirates (UAE), and Qatar, with a different mentality and new ambitions to reform.

Accordingly, all the Gulf States have undertaken various reform measures, the rulers are forced to address subsidies, but they did not need to reduce or abolish all welfare benefits, only the most damaging ones, which was the energy subsidies, because it reduces the state's ability to export, which lead to reduce the revenues distributed to the citizens and create a vicious cycle that threatens the whole rentier system. (Krane, 2019)

At this moment, a new social contract has been created differs from the one stipulated by the rentier theory. (Al-Qassimi, 2016) where imperative of democracy is replaced by maintaining the welfare benefits and keeping the life standard, which means the rentier equation became the Taxation in exchange for security. Therefore, (Krane, 2019) proposed two clauses that could be added to the rentier social contract to make the theory more flexible to the current change in the Gulf states and society, are as follows:

1- Retracting unsustainable benefits - like energy subsidies - is necessary to streamline and strengthen political structures, and could resolve the contradictions between the Gulf's economic and political systems

2- $\quad$ Understanding subsidies as "privilege" that could be replaced or retract flexibly not as "rights".

However, I find what Krane or Al-Qassimi proposed is more like a new theory than a modification of the old one, and I believe that if the basic assumptions of rentier state theory have gone under attack and it is failure enhanced by empirical evidence, so the most convenient way to understand what went wrong with it is to revisit its epistemological roots, which will be covered in the next section.

\subsection{The Roots of The Rentier State Theory's Failure}

We know that the rentier theory arose from the womb of the modernization theory, which stated that social and economic changes brought about by modernization are supposed to lead to the political disruption of non-democratic ruling regimes. However, since this has not occurred in the Gulf states, there is a need for 
another explanation to fill this void, and the alternative, as previously mentioned, was the concept of a "rentier social contract."

I argue that what has made the modernization theory invalid to explain the 1980th and 1990th social reality in the Gulf is the same reason behind the failure of the rentier theory after 2014, as both are established based on an obsolete epistemological framework from the industrial revolution that was not prepared from the early beginning to explain the complex social reality.

Overall, we can say that three typical paradigm shifts occurred in western epistemology (order-chaos-complexity). Each of these transitions began in the natural sciences and then extended to the social sciences, took place in a specific historical period, and knowledge therein possessed special features that differed from what preceded it. Accordingly, rentier state theory was not an exception to that, as being born from the womb of modernization theory, and both were a product of a particular stage of the development of Western thought.

\subsubsection{The Newtonian / Modernity paradigm (Order Paradigm)}

The Renaissance movement in Europe was able to unleash the human intellectual energies until it began to bear fruit in the Age of Enlightenment. During this era, Europe became a center of intellectual, social, and economic transformations, and this coincided with the emergence of certain trends that later formulated the European vision emanating from that stage. For example, René Descartes (1596-1650) called for rationality, while Isaac Newton (1642-1727) revealed a strict set of physic al laws that govern the movement of the universe. Soon after, other discoveries were made in fields as diverse as magnetism, electricity, astronomy, and chemistry, which led to a strong feeling of believing in the power of the reason in dealing with all problems (Geyer, 2004). Then came the Industrial Revolution in the eighteenth and nineteenth centuries, which adopted this new scientific approach.

By the late nineteenth century and early twentieth century, many scientists thought that what was left for them to reach the full disclosure of the secrets of the natural organizing of life is little, and then all that is required is only a few small leaps, the moment In which a person knows everything, because the more the unknown narrows, the more we gain knowledge, this means that with the continuation of time, we will reach the moment of complete knowledge and absolute certainty (or the end of history).

The success of the orderly paradigm in the natural sciences has had a profound effect on ideas and practices in all sectors of human activity, and social science was not an exception. It was first established in the womb of the Industrial Revolution, which in turn was founded on a Newtonian vision of an orderly universe that works regularly like clockwork and follows observable and immutable laws. Therefore, it did not take long for scholars to begin importing the natural sciences. For instance, Thomas used a mechanical vision to form an organized/orderly society, where a leviathan creature protects people from chaos and civil wars, also, the famous British economist Adam Smith claimed to have controlled the laws of economic interaction, while his followers David Ricardo believed that some economic laws were "as affirmed as the principles of gravity" (Geyer, 2012). Karl Marx, in his vision of the class struggle, analyzed the capitalist mode of production intending to create "fixed" and deterministic laws of capitalist development (Badcock, 2007). Thus, academics in all major areas of the social sciences welcomed the new era of certainty and predictability, and economics, politics, and sociology became all "science." This desire was institutionalized through the development of modern universities that created and strengthened discipline and professionalism in the social sciences.

The climax of the orderly paradigm was reached in the 1950s and 1960s, especially in universities in the United States. Thanks to the success of planning programs during World War II and the early post-war period, pressure from the increasing Cold War, and heavy funding from expanding universities; American academics have sought to demonstrate, and then control, the supposedly rational nature of human interactions. This traditional Newtonian approach has been clearly expressed in the modernizing theories of third world development, the realistic view of international relations, the behavioral writings of sociologists, the positivist foundations of liberal economics, as well as the rationalistic plans of public policy experts and social planners. (Geyer, 2004, 2012)

In sum, the knowledge in the orderly period was built on a framework of four rules (Geyer \& Rihani, 2012):

- Order: Given causes result in known effects at all times and places.

- Reductionism: The behavior of any system, such as clockwork, can be accurately and consistently understood by observing the behavior of its parts. Where there are no hidden surprises; this is because the whole is nothing more than a collection of its parts, nothing less.

- Predictability: Once the overall behavior has been defined, it is possible to predict the future course of events 
by applying appropriate inputs to the Form.

- Determinism: processes follow predictable, orderly paths with distinct beginnings and ends.

\subsubsection{The Postmodern Paradigm (Chaos Paradigm)}

By the early twentieth century, Einstein's theory of relativity, Niels Bohr contribution to quantum mechanics, Werner Heisenberg's uncertainty principle and others discovers have played a crucial role in pushing the traditional view beyond Newton's limits that it embraced centuries ago. All these discoveries have revealed that all phenomena are not organized, reducible, or deterministic, nor do they conform to the four associated rules. By the linear regulated paradigm, namely: order, reduction, predictability, and determinism.

Of course, social science started to receive those signals of the change. In the mid-twentieth century, the American philosopher John Dewey defended his philosophy of pragmatism as a strategy for dealing with the limits of knowledge and the uniqueness of human experience, while German sociologists Theodor Adorno and Max Horkheimer were publishing their important work the dialectic of the Enlightenment, in which they criticized the foundations of modernity and the Enlightenment (Geyer, 2004). By the 1970s, the postmodern philosopher Jean-François Lyotard wrote, On Postmodernism: A Report on Knowledge (1984) in which they called for an end to all the "grand narratives" of Western society. As a result, from the 1970s onwards, sociologists have consistently failed to define "laws" of society and economic interaction and have even begun to question Newton's framework that produced political and social thinking in all its directions. (Geyer \& Rihani 2012)

In consequence, a new paradigm arose, differing in its theoretical foundations, expectations, and strategies from the orderly paradigm; Its theoretical foundations are based on skepticism about rationality and the ability of the human mind to predict reality, and then this rebounded in the expectations of those seeking knowledge in that period, as they began to see that it does not advance or delay, and that it is contradictory and based on different and unequal viewpoints, and that all claims the truth is dogmatic and perhaps comprehensive, as it was established by those with power. Therefore, the strategies adopted for research work in that period were based on undermining claims, and techniques of "deconstruction" were used to refute the so-called grand narratives that arose in the era of modernity, and focused on the marginalized "other.", Which was dropped by research during that period, with a constant emphasis on the relationship between knowledge and role of power in controlling knowledge and even establishing it.

\subsubsection{Complexity Paradigm}

Again, after some discoveries in the natural science (in evolutionary biology in particular) in 1970th and 1980th the scholars started to question the foundations of post-modernity epistemology, and seek to invent a new framework for the knowledge "complexity paradigm" extended rapidly to every social science disciplines. The complexity paradigm brought a promise of including diversity and reconciling between the order and disorderly paradigm to produce a balanced knowledge that can express the interconnection and overlapping of our social existence.

In sum, the rules of complexity paradigm could have summarized by (Geyer \& Rihani, 2012) as follows:

- Partial order: phenomena can behave in both orderly and chaotic ways.

- Reductionism and holism: some phenomena are reducible, while others are not.

- Predictability and uncertainty: phenomena can be modeled, predicted, and controlled in part.

- Probabilistic: most phenomena have general boundaries, but exact outcomes are uncertain within these boundaries.

- Adaptation and emergence: they exhibit elements of adaptation and emergence.

- Interpretation: System actors may be aware of themselves, the system, and their history and may attempt to interpret and direct themselves and the system (Geyer, 2012).

\subsubsection{From Rentier Paradigm to Complexity Paradigm}

After we have seen a snapshot about the development journey of western epistemology, it becomes obvious that the rentier state theory is a legal born of the modernity paradigm, it is followed its four rules (order, predictability, determinism, reductionism) and established based on its assumption about the social reality, and it didn't undergo into the development process (from its orderly form to complexity form) to be valid to explain the new reality of social life.

Moreover, the rentier theory's basic question itself, which is "the lack of democracy in the Gulf" manifesting one 
of the most biased products in the modernity paradigm, which is the idea of "progress " that's embraced that the western experience has a validity that goes beyond Western time and place, which led to believe that the course of history is linear, it is moving forward, and the West is considered the top of progress, thus, the assumption of the supremacy of the Western civilization and its universality must be accepted, therefore, it becomes a standard paradigm for all humanity, and the system that everyone must adhere to and follow if they want to bridge the gap between them and the West to reach prosperity and happiness. (Elmessiri, 2006)

Abd al-Wahhab Elmessiri referred to some of the drawbacks of this concept of "progress" and it's ramifications to social research, said "the concept of progress requires the abolition of all values, ideals, and goals, the domination of Western experience over the world, and the generalization of various theories and concepts (especially the social sciences) without taking into account the peculiarities of each society and the different civilizations. It also requires the denial of human experiences, the denial of the importance of the other, and the pursuit of its negation outside the framework of science, history, and even existence (not in the sense of physical existence, but through the distinct presence that expresses identity). Gradually, all people will internalize these Western paradigms and adopt the standards of the Western paradigm to judge themselves. (Elmessiri, 2006)

Finally, I will conclude the essay with this quote from Elmissir's masterpiece Epistemological Bias in the Physical and Social Sciences, that indicated the major biases in the western social research, and among them was the "causal monism" which in my opinion abstracts all drawbacks of the rentier state theory, he said:

"There is a bias toward the simple, the mono-dimensional, and the homogeneous against the complex, the multifaceted, and the heterogeneous. Thus, there is a bias toward simple interpretations that reduce phenomena to one or two variables or principles. Human conduct is interpreted via ... causal monism (explaining phenomena in terms of one decisive cause) ... There is, therefore, an obsessive search for ... a single reason that would explain the universe and that can be taken as the basic core and reference of all." (Elmessiri, 2006)

\section{Conclusion}

The rentier state theory was predominant over the explanation of social and political aspects in the Gulf context since the oil boom in 1971. It was developed in response to the failure of modernization theory to explain the longevity of family-based rulers in the Gulf during the social and political process of modernity, which cemented their rules rather than threatening them, as the modernization theorists were believed. The rentier state theory had its claims, as it explained the survival of the Gulf kingdoms by coined the concept of "rentier social contract," which stated that those Kingdoms are stable because of the welfare benefits and subsidies they provide, and it is predicted that if this contract is disrupted, the legitimacy of the government will be called into question.

However, the evidence on the ground following the 2014 oil shock indicates that neither governments nor citizens have followed the script laid out by rentier state theory, posing a serious challenge to its fundamental assumptions. Therefore, I argued that the rentier state theory failed because it was based on an outdated epistemological paradigm (of modernity) that was unprepared to capture the complexities of the Gulf states and society. As a result, I believe there is an urgent need to include the complexity foundations of our research in Gulf studies as a way of rebalancing the different variables that govern the social phenomenon and producing original knowledge that represents the diversity and interconnectedness of the social reality.

\section{References}

Al-Qassemi. (2016). The Gulf's New Social Contract. Retrieved April 21, 2021, from https://www.mei.edu/publications/gulfs-new-social-contract

Beblawi, H., \& Luciani, G. (1987). The Rentier State in the Arab World. In H. Beblawi \& G. Luciani (Eds.), The Rentier State New York. Croon Helm.

Badcock, A. (2007). Can complexity save development theory? In J. Bogg, \& R. Geyer (Eds.), Complexity, science, and society. Oxford: Radcliffe.

Corden, W., \& Neary, J. (1982). Booming Sector and De-Industrialisation in a Small Open Economy. The Economic Journal, 92(368), 825-848. https://doi.org/10.2307/2232670

Collier, P., \& Hoeffler, A. (1998). On economic causes of civil war. Oxford Economic Papers, 50(4), 563-573. https://doi.org/10.1093/oep/50.4.563

Desai, R. M., Olofsgård, A., \& Yousef, T. M. (2009). The Logic of Authoritarian Bargains. Economics \& Politics, 21(1), 93-125. https://doi.org/10.1111/j.1468-0343.2008.00337.x

Elmessiri, A. (Ed.). (2006). Epistemological Bias in the Physical and Social Sciences. London; Washington: International Institute of Islamic Thought. 
Geyer, R. (2003). European Integration, the Problem of Complexity, and the Revision of Theory. JCMS: Journal of Common Market Studies, 41(1), 15-35. https://doi.org/10.1111/1468-5965.t01-1-00409

Geyer, R. (2004). Europeanisation, complexity, and the British welfare state. Bristol: Policy.

Geyer, R., \& Rihani, S. (2012). Complexity and Public Policy: A New Approach to 21 st Century Politics, Policy, and Society. Taylor and Francis.

Gause, F. G. (1994). Oil monarchies: domestic and security challenges in the Arab Gulf states. New York: Council on Foreign Relations.

Gause, F. G. (1997). The Political Economy of National Security in the GCC States. In G. Sick, \& L. Potter (Eds.), The Persian Gulf at the Millennium. New York: St. Martin's.

Herb, M. (2002). Does rentierism prevent democracy? Paper presented at the annual meeting of the American Political Science Association, Boston Marriott Copley Place, Sheraton Boston \& Hynes Convention Center, Boston, Massachusetts.

Huntington, S. P. (1969). Political order in changing societies (2nd ed.). New Haven \& London: Yale University Press

Karl, T. L. (1997). The Paradox of Plenty: Oil Booms and Petro-States. London: University of California Press, Ltd.

Karl, T. L. (2007). Oil-led development: social, political, and economic consequences. Encyclopedia of energy, 661-672

Krane, J. (2014). Stability versus sustainability: energy policy in the Gulf monarchies (Doctoral thesis). https://doi.org/10.17863/CAM.5943

Krane, J. (2019). Energy kingdoms oil and political survival in the Persian Gulf. New York: Columbia University Press.

Luciani, G. (1987). Allocation vs. Production States: A Theoretical Framework. In H. Beblawi, \& G. Luciani (Eds.), The Rentier State. New York: Croon Helm.

Rutledge, E. (2017). Oil rent, the Rentier State/Resource Curse Narrative and the GCC Countries. OPEC Energy Review, 41(2), 132-152. https://doi.org/10.1111/opec.12098

Ross, M. L. (2001). Does Oil Hinder Democracy? World Politics, 53(3), 325-361. https://doi.org/10.1353/wp.2001.0011

Ross, M. (2012). The Oil Curse: How Petroleum Wealth Shapes the Development of Nations. Princeton; Oxford: Princeton University Press. https://doi.org/10.2307/j.ctt7s3wz

Sachs, J. D., \& Warner, A. M. (2001). The curse of natural resources. European Economic Review, 45(4-6), 827-838. https://doi.org/10.1016/s0014-2921(01)00125-8

Zakaria, F. (2020). Ten lessons for a post-pandemic world. Penguin UK.

\section{Copyrights}

Copyright for this article is retained by the author(s), with first publication rights granted to the journal.

This is an open-access article distributed under the terms and conditions of the Creative Commons Attribution license (http://creativecommons.org/licenses/by/4.0/). 